\title{
Influence of Clipping Frequency on Herbage Yield and Nut- rient Content of Tall Wheatgrass
}

\author{
D. J. UNDERSANDER AND C. H. NAYLOR
}

\begin{abstract}
Graxing or cutting frequency has been shown to affect yield and quality of many grasses, but similar data are lacking for tall wheatgrass [A gropyron elongatum (Host) Beauv. 'Jose']. The objective of the research was to determine the effect of frequency of clipping on tall wheatgrass. The study was conducted at the Texas Agricultural Experiment Station at Bushland, Texas, in 1979, 1980, 1981, and 1984 on a Pullman clay loam soil. Plots were irrigated as needed from February to the end of the growing season and fertilized with $112 \mathrm{~kg} N /$ ha every 2 months for maximum yield and clipped either every week, 2 weeks, of 4 weeks at a $5-\mathrm{cm}$ stubble height. Herbage yield was highest from spring harvests and declined over summer as is typical of cool-season grasses. The plots that were clipped every 4 weeks produced greater herbage yields than plots that were clipped 1 or 2 weeks, suggesting that rotational grazing would increase productivity. The nutrient content of the herbage was highest during summer when herbage yield was lowest. Plants clipped less frequently had the highest concentrations of phosphorus and potassium and the lowest concentrations of calcium and magnesium. The greatest differences in nutrient content occurred among years, which emphasizes the importance of continual herbage analysis to optimize mineral supplementation of graxing cattle.
\end{abstract}

Key Words: Agropyron elongatum, nittrogen, phosphorus, potassium, calcium, magnesium

\footnotetext{
Authors are agronomist and research associate with the Texas Agricultural Experiment Station, Bushland 79012.

Contribution of the Texas Agricultural Experiment Station. Paper number 21098.

Manuscript accepted 19 February 1986.
}

The dry winter and wet summer precipitation pattern of the Southern Plains favors warm-season grasses. Cattle are grazed on wheat (Triticum aestivum L.) pasture during the early November to mid-March period prior to the time when warm-season grasses are available for grazing. This void in available pasture has increased interest in cool-season grasses, particularly where supplemental irrigation is available. In recent years, tall wheatgrass [Agropyron elongatum (Host) Beauv.] has been grown on many hectares in the Southern Plains. This cool-season grass begins growth early in March most years and provides pasture near the time cattle are taken off wheat pasture. Little information is available on the management of this grass in the Southern Plains. Schuster and Garcia (1973) reported tall wheatgrass to be the easiest to establish of several cool-season species evaluated in the Texas Panhandle. They further reported that tall wheatgrass would be available for grazing in late September through November until wheat was available for grazing and that it could be grazed in the spring beginning in April when the cattle are removed from wheat pasture. They found that tall wheatgrass survived under dryland conditions when other cool-season grasses, that yielded more under full irrigation, did not survive.

Clipping has been shown to increase herbage yields of some species, (Drawe et al. 1972, Eck et al. 1975, Svejcar and Rittenhouse 1982) while clipping too frequently reduced yields and reduced plant survival of crested wheatgrass (Carter and Law 1948) and of rough fescue (McLean and Wikeem 1985). Pitman and Holt (1983), when evaluating 2-, 4-, and 8-week harvest frequencies of kleingrass ( Panicum coloratum L.), green sprangletop 
(Leptochloa dubia (H.P.K.) Nees), and plains bristlegrass (Setaria macrostachya H.P.K.), found that the 8-week clipping frequency generally increased dry matter production of the grasses, and also found that the 4-week harvest frequency produced optimum yields of highly digestible, leafy herbage.

Similar information on the effects of clipping frequency is not available for tall wheatgrass. Further, there is little information on seasonal changes or effects of frequency of clipping or grazing on nutrient content. Such information may be useful for suggesting supplementation regimes for cattle grazing tall wheatgrass.

The objectives of this research were to evaluate the effect of frequency of clipping on yield and nutrient content of tall wheatgrass over the growing season.

\section{Materials and Methods}

Tall wheatgrass cv. 'Jose' was established in pure stands in level bordered field plots during the fall of 1978 and 1983 . The soil was a Pullman clay loam (fine, mixed, thermic Torrertic Paleustoll). Plots were fertilized with $112 \mathrm{~kg} \mathrm{~N} / \mathrm{ha}$ as ammonium nitrate, at the end of February, April, June, and August of 1979-1984. Plots were irrigated from the beginning of February until mid-October whenever visual symptoms of stress occurred. Approximately $5 \mathrm{~m}$ water per week was applied to the plots during peak water use periods, less during spring and fall.

Treatments consisted of 3 frequencies of clipping: every 1,2 , or 4 weeks. Treatments, in $1.2 \times 3-\mathrm{m}$ plots, were arranged in a randomized complete block design with 3 replications. Once randomized, plot areas were not changed during 1979 to 1981. No observable stand changes occurred that could be attributed to clipping frequency. Data from 1984 were from a new seeding made in September 1983. Entire plots were clipped with a lawn mower at 5 -cm stubble height and accumulated at dates shown in Table 1 when

Table 1. Four-week harvest dates and dates at which yields were collected and nutrient contents determined for Jose Tall Wheatgrass at Bushland, Texas.

\begin{tabular}{ccccl}
\hline & \multicolumn{4}{c}{ Year } \\
\cline { 2 - 5 } Harvest & 1979 & 1980 & 1981 & 1984 \\
\hline 1 & 8 May & 2 June & 8 June & 16 May \\
2 & 8 June & 25 June & 6 July & 27 June \\
3 & 16 July & 29 July & 3 Aug. & 25 July \\
4 & 16 Aug. & 21 Aug. & 3 Sep. & 22 Aug. \\
5 & 21 Sep. & 25 Sep. & 29 Sep. & 20 Sep. \\
6 & 17 Oct. & 24 Oct. & 29 Oct. & 18 Oct. \\
\hline
\end{tabular}

4-week clippings occurred. Individual harvest samples were oven dried at $60^{\circ} \mathrm{C}$ for 72 hours and weighed. Yields were totaled for each replicate of each treatment for each 4-week period.

Nutrient analyses were determined only on samples collected when all $\mathbf{3}$ frequencies of clipping were harvested on the same day. Oven-dried samples were ground through a $1-\mathrm{mm}$ screen in a Wiley

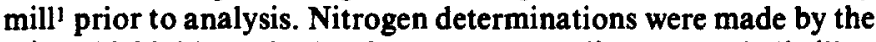
micro-kjeldahl method using a Tecator digestor and distiller. Other nutrients were determined on ground samples ashed in a muffle furnace at $450^{\circ} \mathrm{C}$ for 6 hours. The ash was then dissolved in $5 \mathrm{ml}$ of $4 \mathrm{~N}$ hydrochloric acid and brought to $25 \mathrm{ml}$ final volume. Phosphorus content of the digest was determined by the vana-domolybdophosphoric acid-yellow procedure (Assoc. Off. Anal. Chem., 1980) while potassium, calcium, and magnesium were determined by atomic absorption on a Perkin Elmer 4000 spectrophotometer. Calcium and magnesium determinations were made in $0.18 \mathrm{M}$ lanthanum oxide/hydrochloric acid solution.

Yields, totaled for 4-week periods, and compositional data were analyzed by analysis of variance using the Statistical Analysis System. Harvests were considered to be nested within years. Where

Mention of a trademark is for informational purposes only and does not constitute endorsement of the product by the Texas Agricultural Experiment Station. a significant $F$ value occurred, Student-Newman-Keuls' multiple range test was used to separate means.

\section{Results and Discussion}

Annual herbage yields ranged between 8,690 and $15,980 \mathrm{~kg} / \mathrm{ha}$ during 1979 to 1981 (Table 2) while yields were in a considerably lower range during 1984. The 1984 data were collected from a

Table 2. Forage production of Jose tall wheatgrass totaled over 6-four week intervals for each clipping frequency during each year at Bushland, TX.

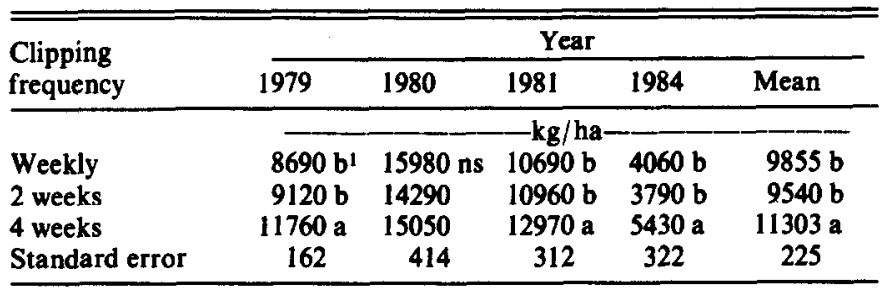

Standard error $=302$

'Means within a column followed by the same letter are not significantly different, Student Newman-Keuls' ( $P<0.05$ for individual years and $P<0.01$ for mean).

different planting than the first 3 years of the study; however, stand density was sufficient for considerably greater yields and other management practices were similar to those of previous years. The daily low temperatures were lower later into the spring in 1984 (Fig. 1) than in other years of the study. This cool weather undoubtedly reduced forage growth for the first harvest and resulted in the considerable reduction in total herbage production for the year.

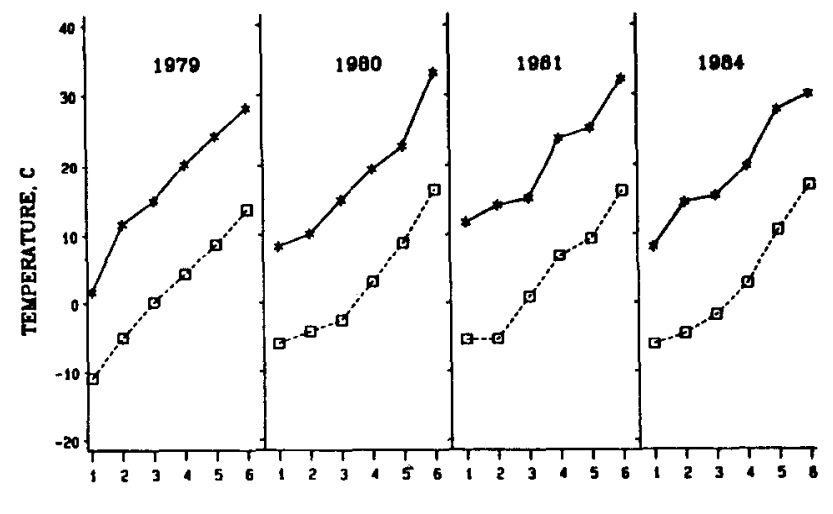

YONTH

Fig. 1. Mean monthly maximum and minimum temperatures at Bushland, Texas, during January to June.

No significant difference in yield occurred among plots clipped weekly or biweekly. The plots that were clipped monthly yielded 12 and $18 \%$ more than those clipped weekly or bi-weekly, respectively. The data are basically in agreement with data of previous researchers (Drawe et al. 1972, Eck et al. 1975, Pittman and Holt 1983, Mutz and Drawe 1983), which indicate some clipping during the growing season can increase herbage yield, but clipping too frequently can decrease herbage yields. Moore et al. (1981) reported that there was no difference under irrigation in yield or quality of Jose tall wheatgrass when clipped at either 5-cm or $12.7-\mathrm{cm}$ or 21 day intervals. Frequent clipping, particularly at a low stubble height, may reduce photosynthetic area to the extent that photosynthate is not available for regrowth after clipping. This would suggest, that under intensive management, pastures should be rested periodically to maximize herbage yields.

Herbage yields of the 3 clipping frequencies for each 4-week harvest period are presented in Figure 2. The yield difference among the treatments occurred in 1979 at the second harvest where 

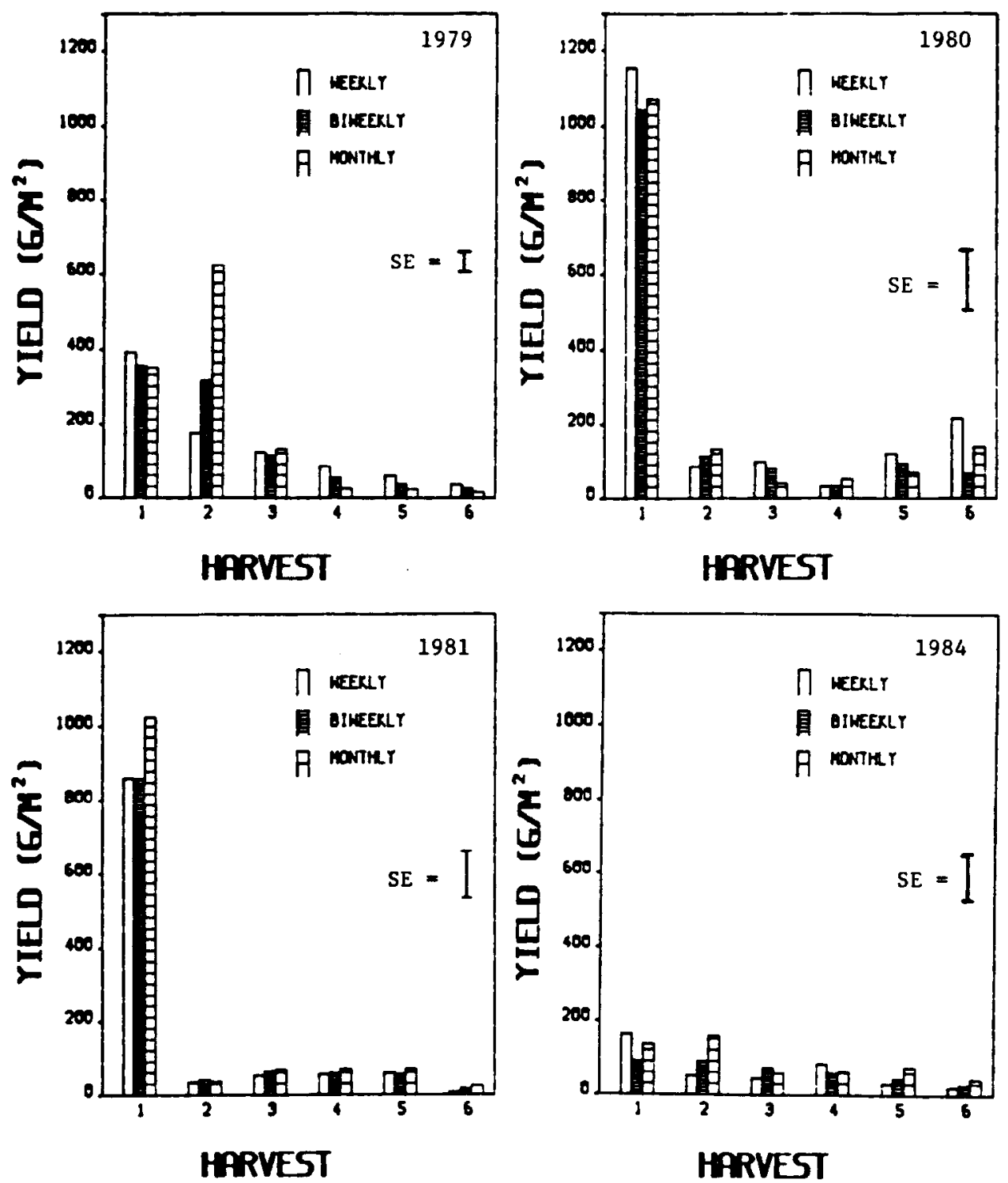

Fig. 2. Herbage yield of tall wheatgrass at 6 harvest periods for 3 clipping frequencies during 1979, 1980,1981 and 1984.

less frequently clipped plots yielded more. Harvest 1 occurred between the middle of May and the first week of June each year while harvest 2 occurred during the last week of June or the first week of July. Less frequent clipping may have allowed the higher rate of spring growth to continue for a longer period. In 1981 and 1984 , the higher total annual yield of the plots clipped every 4 weeks resulted from nonsignificant trends in higher yield of this treatment throughout the growing season.

The nitrogen content of herbage was not affected by the 3 clipping frequencies (Table 3 ). The results are somewhat surprising because, generally as herbage matures, the nitrogen content declines (Van Soest 1983). Tall wheatgrass is considered to be a late maturing cool-season grass, which may mean that the normally observed trend would have occurred in older material than 4 weeks. The herbage remained in vegetative stages during all samplings. Therefore, maturity may not have been an important factor in determining nitrogen content. Further, nitrogen content of the tall wheatgrass remained at higher levels than reported for other grass species (Mutz and Drawe 1983, Koshi et al. 1982, Eck et al. 1981). This may have occurred because the plots were heavily fertilized and irrigated, which may have resulted in higher nitrogen content than under other conditions. However, the experience of this author has been that tall wheatgrass tends to maintain higher nitrogen content than other species grown in the region, even at low levels of fertilization.

Potassium and phosphorus contents were lower in herbage from the more frequently clipped plots while calcium and magnesium were higher. Potassium decreased from $2.22 \%$ in the plots clipped every 4 weeks to $2.03 \%$ in the weekly clipped plots. While differences among treatments were not always significant within years, trends were fairly consistent. All levels were above the minimum requirement of animals (National Research Council 1976) and thus the changes in levels of this nutrient may be of little consequence in grazing systems. Phosphorus declined from $0.19 \%$ to $0.17 \%$ in the respective treatments but differences were generally not significant within years. Calcium and magnesium contents were not affected by clipping frequency in some years but the overall effect was for calcium to increase from 0.37 to $0.43 \%$ and magnesium to increase from 0.16 to $0.18 \%$ as clipping frequency increased.

The most striking observation from the nutrient analysis of tall wheatgrass herbage was that the highest content of each nutrient occurred in harvest 3 or 4 during the mid-summer period (Table 4). Speculatively, this may arise from the lack of water stress during the summer period when growth is restricted by high temperatures. 
Table 3. Nitrogen, potassium, phosphorus, calclum, and magnesium content of Jose tall wheatgrass averaged over 6-four week intervals for 3 clipping frequencies in 4 years at Bushland, $T X$.

\begin{tabular}{|c|c|c|c|c|c|c|}
\hline \multirow[b]{2}{*}{ Year } & \multirow{2}{*}{$\begin{array}{l}\text { Clipping } \\
\text { Frequency }\end{array}$} & \multicolumn{5}{|c|}{ Nutrient } \\
\hline & & Nitrogen & Potassium & Phosphorus & Calcium & Magnesium \\
\hline 1979 & $\begin{array}{l}\text { Weekly } \\
2 \text { weeks } \\
4 \text { weeks }\end{array}$ & $\begin{array}{l}2.30 \mathrm{~ns} \\
2.14 \\
2.48\end{array}$ & $\begin{array}{l}2.19 \mathrm{a}^{\mathrm{l}} \\
1.73 \mathrm{~b} \\
2.50 \mathrm{a}\end{array}$ & $\begin{array}{l}0.14 \text { ns } \\
0.14 \\
0.15\end{array}$ & $\begin{array}{l}0.46 \mathrm{~ns} \\
0.46 \\
0.45\end{array}$ & $\begin{array}{l}0.16 \text { ns } \\
0.15 \\
0.16\end{array}$ \\
\hline 1980 & $\begin{array}{l}\text { Weekly } \\
2 \text { weeks } \\
4 \text { weeks }\end{array}$ & $\begin{array}{l}2.53 \mathrm{~ns} \\
2.90 \\
2.71\end{array}$ & $\begin{array}{l}2.07 \text { ns } \\
2.24 \\
2.25\end{array}$ & $\begin{array}{l}0.17 \text { ns } \\
0.18 \\
0.17\end{array}$ & $\begin{array}{l}0.51 \mathrm{~ns} \\
0.59 \\
0.49\end{array}$ & $\begin{array}{l}0.20 \mathrm{~ns} \\
0.23 \\
0.18\end{array}$ \\
\hline 1981 & $\begin{array}{l}\text { Weekly } \\
2 \text { weeks } \\
4 \text { weeks }\end{array}$ & $\begin{array}{l}3.43 \mathrm{~ns} \\
3.60 \\
3.10\end{array}$ & $\begin{array}{l}1.62 \mathrm{~ns} \\
1.72 \\
1.94\end{array}$ & $\begin{array}{l}0.14 \mathrm{~b} \\
0.19 \mathrm{a} \\
0.19 \mathrm{a}\end{array}$ & $\begin{array}{l}0.43 \mathrm{~ns} \\
0.37 \\
0.29\end{array}$ & $\begin{array}{l}0.20 \mathrm{a} \\
0.18 \mathrm{a} \\
0.14 \mathrm{~b}\end{array}$ \\
\hline 1984 & $\begin{array}{l}\text { Weekly } \\
2 \text { weeks } \\
4 \text { weeks }\end{array}$ & $\begin{array}{l}3.51 \mathrm{~ns} \\
3.44 \\
3.44\end{array}$ & $\begin{array}{l}2.25 \mathrm{~ns} \\
2.20 \\
2.28\end{array}$ & $\begin{array}{l}0.22 \mathrm{~ns} \\
0.22 \\
0.20\end{array}$ & $\begin{array}{l}0.30 \mathrm{~ns} \\
0.31 \\
0.31\end{array}$ & $\begin{array}{l}0.16 \text { ns } \\
0.15 \\
0.16\end{array}$ \\
\hline $\begin{array}{l}\text { Standard Error } \\
\text { Mean }\end{array}$ & $\begin{array}{l}\text { Weekly } \\
2 \text { weeks } \\
4 \text { weeks }\end{array}$ & $\begin{array}{l}0.26 \\
2.94 \text { ns } \\
3.02 \\
2.93\end{array}$ & $\begin{array}{l}0.20 \\
2.03 \mathrm{~b} \\
2.05 \mathrm{~b} \\
2.22 \mathrm{a}\end{array}$ & $\begin{array}{l}0.01 \\
0.17 \mathrm{~b} \\
0.19 \mathrm{a} \\
0.19 \mathrm{a}\end{array}$ & $\begin{array}{l}0.05 \\
0.43 \mathrm{a} \\
0.44 \mathrm{a} \\
0.37 \mathrm{~b}\end{array}$ & $\begin{array}{l}0.02 \\
0.18 \mathrm{a} \\
0.18 \mathrm{a} \\
0.16 \mathrm{~b}\end{array}$ \\
\hline
\end{tabular}

'Means within a column for each year followed by the same letter are not significantly different, Student Newman-Keuls $(P<0.01)$.

Transpiration, and therefore water uptake from the soil, continued because water was not limiting due to the irrigation procedure. Thus, mineral uptake was continuing and, since growth was decreased (Fig. 1) by the elevated temperatures, the concentration of nutrients in the herbage was increased.

Table 4. Four year average nitrogen, potassium, phosphorus, calcium, and magnesium content of Jose tall wheatgrass for 6 harvest periods at Bushind, TX.

\begin{tabular}{|c|c|c|c|c|c|}
\hline \multirow[b]{2}{*}{$\begin{array}{c}\text { Harvest } \\
\text { Period }\end{array}$} & \multicolumn{5}{|c|}{ Nutrient } \\
\hline & $\begin{array}{l}\text { Nitro- } \\
\text { gen }\end{array}$ & $\begin{array}{l}\text { Potas- } \\
\text { sium }\end{array}$ & $\begin{array}{l}\text { Phos- } \\
\text { phorus }\end{array}$ & $\begin{array}{l}\text { Cal- } \\
\text { cium }\end{array}$ & $\begin{array}{l}\text { Mag- } \\
\text { nesium }\end{array}$ \\
\hline & & & $-6 \%$ & & \\
\hline 1 & $2.7 \mathrm{cl}^{1}$ & $2.18 \mathrm{~b}$ & $0.18 \mathrm{~b}$ & $0.32 \mathrm{~d}$ & $0.12 \mathrm{c}$ \\
\hline 2 & $3.1 \mathrm{ab}$ & $2.07 \mathrm{~b}$ & $0.18 \mathrm{~b}$ & $0.47 \mathrm{~b}$ & $0.21 \mathrm{~b}$ \\
\hline 3 & $3.3 \mathrm{a}$ & $2.33 \mathrm{a}$ & $0.21 \mathrm{a}$ & $0.35 \mathrm{~cd}$ & $0.18 \mathrm{c}$ \\
\hline 4 & $3.3 \mathrm{a}$ & $2.47 \mathrm{a}$ & $0.18 \mathrm{~b}$ & $0.52 \mathrm{a}$ & $0.24 \mathrm{a}$ \\
\hline 5 & $3.1 \mathrm{ab}$ & $2.09 \mathrm{~b}$ & $0.18 \mathrm{~b}$ & $0.40 c$ & $0.18 \mathrm{c}$ \\
\hline 6 & $2.9 \mathrm{bc}$ & $1.62 \mathrm{c}$ & $0.17 b$ & $0.39 c$ & $0.15 \mathrm{~d}$ \\
\hline \multicolumn{6}{|l|}{ Standard } \\
\hline Error & 0.075 & 0.057 & 0.004 & 0.017 & 0.006 \\
\hline
\end{tabular}

iMeans within a column followed by the same letter are not significantly different, Student Newman-Keul's $(\boldsymbol{P}<0.01)$.

While significant differences occurred between clipping frequencies and during the growing season, the largest changes in nutrient content were among years of the study (Table 5). The concentrations of nutrients in the herbage other than magnesium varied by $50 \%$ or more among the years of the study. Calcium was highest the first 2 years of the study $(0.50 \%$ and $0.53 \%)$ when nitrogen concentration was lowest and lower the last 2 years of the study $(0.36 \%$ and $0.31 \%)$ when nitrogen concentration was highest. Magnesium was significantly $(P<0.01)$ higher in the samples collected in 1980 than in the samples collected during the other years of the study. With the exception of nitrogen and potassium, the nutrients ranged from deficiency to sufficiency for livestock during the years of the study. This points to the need for sampling and analyzing herbage cattle are grazing to determine the appropriate mineral supplementation.

In summary, when Jose tall wheatgrass was produced under irrigation with nitrogen fertilization and clipped at 3 frequencies (every week, 2 weeks, and 4 weeks), less frequent (every 4 weeks) clipping produced the highest yields. While nutrient differences
Table 5. Average nitrogen, potasaium, phosphorus, calcium, and magnesium content of Jose tall whent grass during 1979, 1980, 1981, and 1984 at Bushland, Texas.

\begin{tabular}{|c|c|c|c|c|c|}
\hline \multirow[b]{2}{*}{$\begin{array}{r}\text { Harvest } \\
\text { Period }\end{array}$} & \multicolumn{5}{|c|}{ Nutrient } \\
\hline & $\begin{array}{l}\text { Nitro- } \\
\text { gen }\end{array}$ & $\begin{array}{l}\text { Potas- } \\
\text { sium }\end{array}$ & $\begin{array}{l}\text { Phos- } \\
\text { phorus }\end{array}$ & $\begin{array}{l}\text { Cal- } \\
\text { cium }\end{array}$ & $\begin{array}{l}\text { Mag- } \\
\text { nesium }\end{array}$ \\
\hline & & & $-\%$ & & \\
\hline 1979 & $2.3 \mathrm{cl}^{1}$ & $2.11 \mathrm{~b}$ & $0.14 \mathrm{~b}$ & $0.50 \mathrm{a}$ & $0.17 b$ \\
\hline 1980 & $2.7 \mathrm{~b}$ & $2.19 \mathrm{~b}$ & $0.17 b$ & $0.53 \mathrm{a}$ & $0.20 \mathrm{a}$ \\
\hline 1981 & $3.4 \mathrm{a}$ & $1.76 \mathrm{c}$ & $0.17 b$ & $0.36 \mathrm{~b}$ & $0.17 \mathrm{~b}$ \\
\hline 1984 & $3.5 \mathrm{a}$ & $2.50 \mathrm{a}$ & $0.21 \mathrm{a}$ & $0.31 \mathrm{c}$ & $0.16 \mathrm{~b}$ \\
\hline \multicolumn{6}{|l|}{ Standard } \\
\hline Error & 0.06 & 0.042 & 0.01 & 0.013 & 0.004 \\
\hline
\end{tabular}

'Means within a column followed by the same letter are not significantly different, Student Newman-Keuls', $(P<0.01)$.

among treatments were frequently not significant, over the 4 years of the study, less frequently clipped plants had the highest concentration of phosphorus and potassium and the lowest concentration of calcium and magnesium. This would indicate that rotational grazing would tend to result in higher herbage production than continuous grazing and may require different mineral supplementation to optimize animal production. Herbage harvested during mid-summer contained the highest concentration of nutrients. The greatest, however, variation in nutrient content was among years.

\section{Literature Cited}

Ass. Off. Anal. Chem. 1980. Official methods of analysis, 13th ed. Ass. Off. Anal. Chem. Washington, D.C.

Carter, J.F., and A.G. Law. 1948. The effect of clipping upon the vegetative development of some perennial grasses. Agron. J. 40:1084-1091.

Drawe, D.L., J.B. Grumbles, and J.F. Hooper. 1972. Clipping effects on seeded foothill ranges in Utah. J. Range Manage. 25:426-429.

Eck, H.V., W.G. McCully, and J. Stubbendieck. 1975. Response of shortgrass plains vegetation to clipping, precipitation, and soil water. $J$. Range Manage. 28:194-197.

Eck, H.V., G.L. Wilson, and Tito Martinez. 1981. Tall fescue and smooth bromegrass. II. Effects of nitrogen fertilization and irrigation regimes on quality. Agron. J. 73:453-456.

Koshi, P.T., J. Stubbendieck, H.V. Eck, and W.G. MeCully. 1982. Switchgrasses: forage yield, forage quality and water-use efficiency. J. Range Manage. 35:623-627. 
MeLean, A., and S. Wlkeem. 1985. Rough fescue response to season and intensity of defoliation. J. Range Manage. 38:100-103.

Moore, J., J.M. Murphy, F.M. Roquette, Jr., and E.C. Holt. 1981. Influence of defoliation height and frequency on yield and in vitro dry matter digestibility of Jose tall wheatgrass. Texas A\&M, Soil and Crop Sci. Dep. Tech. Rep. 81-12.

Mutz, J.L., and D.L. Drawe. 1983. Clipping frequency and fertilization influence herbage yields and crude protein content 4 grasses in South Texas. J. Range Manage. 36:582-585.

National Research Council. 1976. Nutrient requirements of domestic animals; No. 4, Beef Cattle, 5th Ed., Nat. Acad. Sci., Washington, D.C.
Pitman, W.D., and E.C. Holt. 1983. Herbage production and quality of grasses with livestock and wildlife value in Texas. J. Range Manage. 36:52-54.

Schuater, J.S., and R.C. de Leon Garcin. 1973. Phenology and forage production of cool season grasses in the Southern Plains. J. Range Manage. 26:336-339.

Svejcar, T., and L.R. Rittenhouse. 1982.Standing crop and vigor of defoliated Russian wildrye in southwestern Colorado. J. Range Manage. 35:595-597.

Van Soest, P.J. 1982. Nutritional ecology of the ruminant. O \& B Books, Inc. Corvallis, Ore. 